Original Paper

doi 10.15826/recon.2019.5.3.013

\title{
Analysis of Japanese shrinking cities and policies to tackle this problem (the case of Sammu city and its economic gardening project)
}

\section{T. Yamamoto \\ Takushoku University, Tokyo, Japan; e-mail: ytakashi@ner.takushoku-u.ac.jp}

\begin{abstract}
This paper examined the problem of shrinking cities and evaluated the policies used to mitigate the impact of shrinkage. The analytical section of this paper discusses the definition of a shrinking city, Japan's depopulation in the coming decades on the national and municipality level, and the vicious circle of the population loss and the change of economic structure in shrinking Japanese cities. The second section of the paper examines the desired policy goals for shrinking cities, along with strategies and approaches to achieve them. It is shown that the strategies that the Japanese national government has realized since 2014 were inadequate and ineffective. An alternative initiative (for example, the economic gardening model) is necessary to complement governmental programs to empower SMEs in cities, create more jobs and boost the incomes of businesses and city residents. The case study section of this paper analyzed the case of Sammu - a shrinking Japanese city, which has been engaged in an economic gardening project. Even though the outcomes of this project have not been officially confirmed, the available data show that the sales and employment of the local firms that participated in the program either improved or at least remained at the same level. The potential area for future research might be analysis of programs for revitalizing shrinking cities in resource-dependent regions, for instance, of Russia and Australia. Such studies could provide insightful suggestions for adequate policy formulation and implementation.
\end{abstract}

\section{KEYWORDS}

depopulation, regional cities, smalland medium-sized enterprises (SMEs), economic gardening, Japan ACKNOWLEDGEMENTS The research was supported by JSPS KAKENHI Grant Number JP18K02007. Any opinion, findings, and conclusions or recommendations expressed in this paper are those of the author and do not necessarily reflect the views of the author's organization, Sammu City Government, JSPS, MEXT, or Japanese Government. FOR CITATION

Yamamoto T. (2019) Analysis of Japanese shrinking cities and policies to tackle this problem (the case of Sammu city and its economic gardening project). R-economy, 5(3), 123-136. doi: 10.15826/ recon.2019.5.3.013

\section{Анализ японских сокращающихся городов и политика для решения этой проблемы (пример города Самму и его проекта экономического садоводства)}

\section{Т. Ямамото}

Университет Такусёку (Токио, Япония); email: ytakashi@ner.takushoku-u.ac.jp

\section{АННОТАЦИЯ}

В статье рассматривается проблема сокращения городов и оценивается политика, используемая для смягчения последствий данного сокращения. В аналитическом разделе этой статьи обсуждается определение сокращающегося города, депопуляция Японии в предстоящие десятилетия на национальном и муниципальном уровне, а также связь потерь населения и изменения экономической структуры в сокращающихся японских городах. Во втором разделе рассматриваются желаемые цели политики в отношении сокращения городов, а также стратегии к их достижению. Показано, что стратегии, реализованные японским национальным правительством с 2014 г., были неэффективными. Альтернативная инициатива (например, модель экономического садоводства) необходима в дополнение к государственным программам по расширению возможностей малых и средних предприятий в городах, созданию новых рабочих мест и повышению доходов предприятий и городских жителей. В статье проанализирован случай Самму - сокращающегося японского города, который участвовал в проекте экономического садоводства. Хотя результаты этого проекта официально не подтверждены, имеющиеся данные показывают, что продажи и занятость местных фирм, участвовавших в программе, либо улучшились, либо, по крайней мере, остались на том же уровне. Потенциальной областью будущих исследований может быть анализ программ по оживлению сокращающихся городов в ресурсозависимых регионах, например, России и Австралии. Такие исследования могут дать полезные предложения для адекватной разработки и реализации политики.

(c) T. Yamamoto, 2019

\section{КЛЮЧЕВЫЕ СЛОВА}

депопуляция, региональные города, малые и средние предприятия

(МСП), экономическое садоводство, Япония

\section{БЛАГОДАРНОСТИ}

Исследование было поддержано грантом JSPS KAKENHI JP18K02007. Любое мнение, выводы или рекомендации, выраженные в этом документе, принадлежат автору и не обязательно отражают точку зрения организации автора, правительства города Самму, JSPS, MEXT или правительства Японии.

\section{ДЛЯ ЦИТИРОВАНИЯ}

Yamamoto T. (2019) Analysis of Japanese shrinking cities and policies to tackle this problem (the case of Sammu city and its economic gardening project). R-economy, 5(3), 123-136. doi: 10.15826/ recon.2019.5.3.013 


\section{Introduction}

Shrinkage of cities has been both a domestic and international issue and has attracted the attention of economists, economic geographers, sociologists, urban and regional planners. Actors in political, civil, and private sectors are also concerned about the causes, process, and consequences of city shrinkage. Population loss and collapse of communities in big cities such as Detroit attracts academic and public attention, but shrinkage of regional small cities is related to more important and complicated issues. This paper discusses shrinking Japanese cities in the age of sustainable development goals (SDGs).

This paper has three purposes. The first purpose is to analyze the theoretical and practical aspects of the problem of shrinking cities. I will start by discussing the definition of a shrinking city and provide a brief literature review. Then I will focus on the shrinkage of Japanese cities and the background for this phenomenon: Japan is now facing a "slow-burning" nation-wide depopulation crisis and the situation is going to become worse in the coming decades. This alarming trend persists even though Japanese governments, both national and municipal, have been struggling to solve this problem. I will clarify the characteristics of Japanese shrinking cities and discuss the causes of the loss of population and deteriorating economic activities there.

Second, this paper examines the desired policy goals for shrinking cities, along with the strategies and approaches to achieve such goals. I will show that instead of simply increasing the income and employment levels among the residents, it is necessary to enhance the economic resilience in shrinking cities. I will also argue that the strategies that the national government has implemented since 2014 have been inadequate and have therefore failed to solve this problem. I will then propose an alternative approach, which focuses on the areas that the Japanese government has not paid much attention to - economic gardening. This alternative approach was already tested in the US, Australia and Japan and could help tackle the problem of shrinking cities.

Third, this paper proposes a framework for comparative case study analysis on shrinking cities which could be used, for instance, to compare cities in Russia and Japan. There is an urgent need for research on shrinking cities in resource-dependent regions in order to promote sustainable development of these cities. This paper seeks to fill this gap by supplying a framework for comparative analysis. This paper will also present a case study of a Japanese city based on the proposed framework as an example of the above-mentioned alternative approach. I will provide some basic information about this city and the program, then discuss the challenges that had to be addressed and the results of the program implementation.

Issues related to shrinking cities include from public health, loss of young workers, loss of businesses, abandoned houses and farmlands, city planning and management, and maintenance of the infrastructure. While all of these issues are important and need comprehensive solutions, this paper cannot cover all of them, and instead focuses on issues related to income and employment in shrinking cities. Chronologically, this paper discusses the shrinkage of cities after the 1990s, and the information on shrinking cities before the 1990s is used as references.

\section{Analysis}

\section{Definition of a shrinking city}

One of the difficulties of defining a shrinking city is that understanding of this phenomenon to a great extent depends on the context of each specific country. For example, in Japan, since the mid-1960s, the issue of depopulation and the loss of community sustainability was referred to as "kaso", which literally means "being overly-sparsely populated". The Subcommittee of the Economic Council on Regional Issues, a Japanese governmental organization, explained the "kaso" issue in the report published on 30 October 1967 the following way: “... we understand "kaso" as a state when it becomes difficult to maintain a certain level of living because of depopulation: for example, when it becomes difficult to maintain basic conditions of local community such as disaster prevention, education, and preservation of health; at the same time, when it becomes difficult to use resources rationally; and then the production output in the area reduces significantly. Depopulation leads to lower population density and aging and makes it difficult for the community to maintain a sustainable lifestyle" (English translation was made by the author).

\footnotetext{
${ }^{1}$ Quoted in the collection of official reports published by governmental organizations: "Kaso Taisaku no Keii Enkaku (History and Variation of Kaso Issues)". Retrieved from: http:// www.soumu.go.jp/main sosiki/jichi gyousei/c-gyousei/2001/ kaso/pdf/kasokon19 01 s2.pdf
} 
The Act on Special Measures Concerning the Promotion of Self-Sustainability in Kaso Areas provides another definition of a " $k a s o$ " area. The Act, enacted in March 2000 and revised in 2017, follows the preceding laws since 1970 but expands the definition of "kaso": a municipality can be recognized as a "kaso" area by concerned ministers based on the status of the financial capacity index, average depopulation rate in the past, and seniority rate in the municipality.

Since the notion of "kaso" becomes meaningful only in the Japanese context, it is pretty hard to apply this term in the international discussion, for example, to discuss matters related to other countries. Therefore, this paper employs the definition of a shrinking city provided by the Shrinking Cities International Research Network (SCIRN): "a densely populated urban area with a minimum population of 10,000 residents that has faced population losses in large parts for more than two years and is undergoing economic transformations with some symptoms of a structural crisis" [1].

\section{Research questions}

The existing literature has already covered various aspects of the phenomenon of shrinking cities on global, supra-national, and national levels, for example, there is a case study of cities in the US, Germany, Italy, and the UK [2]. Richardson and Nam also provide a classification of causes and consequences of urban shrinkage and describe the measures for improvement of the current situation [2].

The analysis of shrinking cities in the eastern part of Germany shows that it is a complex, multi-dimensional problem [3]. First, demographic problems are caused by the decline in population due to low birth rates, migration of the youth, and aging. Second, urban economic problems involve the loss of employment due to de-industrialization, and job losses are linked to de-industrialization and, therefore, cannot be compensated for by the growth within the service sector. Third, urban problems include public infrastructure overcapacity, large brownfield areas, and vacant residential and commercial property. Finally, these demographic and socio-economic processes result in the deterioration of the financial conditions within the struggling municipalities, which limits the local government's choice of policy instruments.

Taking the national and local conditions into account and focusing on the causes of shrinkage, we can point out three types of shrinkage: (1) shrinkage imposed either by natural or external forces (including those external to the local region); (2) shrinkage due to comparative disadvantage; and (3) shrinkage due to societal and global changes [4]. In the first category of "imposed shrinkage", the underlying causes of shrinkage are, for example, political and military conflicts, spatial and administrative reforms (initiated by the national government) or resource depletion. These causes are beyond the control of the local community. The second category of "shrinkage due to comparative disadvantage" reflects the cases when cities become unable to compete with other cities due to inadequate infrastructure, technology, the cost and quality of labor force, changes in the performance of their main industries, business environment, and people's lifestyle. The third category of "societal and global changes" refers to the changes, such as a continuous decline of birth rates and climate change. Since these factors are beyond the control of these communities, the only thing they can do is to cope with the situation by developing strategies that maximize their opportunities.

Yang and Dunford studied the shrinkage of urban and rural areas in Chinese municipalities and compared different types of causes in different regions of China [5]. Their contribution to the discussion is important because they show that there are different reasons for city shrinkage even in the same country.

There is a perceived lack of research literature on the city shrinkage in resource-dependent regions: even though some regions are endowed with fertile land or natural resources, cities in the region may start experiencing shrinkage while their resources are still available. Many municipalities in Russia and Japan fall into this category, and further research on how such municipalities can be revitalized is needed. International joint research on this topic, involving academics in Russia, Japan, and other countries such as Australia and the US, will contribute to the understanding of this problem by making insightful suggestions about the most efficient policies and their implementation.

\section{The issue of depopulation in Japan on the national level}

Japan currently experiences and will continue experiencing in the future depopulation and aging on an unprecedented scale. As of 1 October, 2018, the population of Japan is 126.4 million, 
lower than the previous year by 263 thousand people. There are 35.6 million senior citizens aged 65 or older, and the seniority rate has reached its historical maximum of $28.1 \%$. The total fertility rate in 2018 was 1.42, which is well below the level that can maintain the population.

According to the recent estimates based on the National Population Census of 2015, the total population of Japan in 2045 will decline to 106.4 million [6, p. 47]. This means that $16.3 \%$ of the population will be lost in 30 years. The loss of population is mainly due to the continuously falling birth rates. The longer lifespan, along with the lower birth rate, leads to an increase in the aging population. The same report also estimates that the seniority rate will become higher in all of the 47 prefectures in Japan [6, pp. 50-52]. The number of prefectures with the seniority rate exceeding 30\% was 13 out of 47 in 2015, but it is expected that the seniority rate will exceed $30 \%$ in all of the prefectures in 2045. The national average of the seniority rate will be $36.8 \%$ in 2045 , but the variance is large. The highest seniority rate in 2045 will be found in Akita Prefecture (50.1\%), and the lowest - in Tokyo Metropolitan (30.7\%). The trends of depopulation and aging will continue and accelerate. The loss of working population combined with the increasing senior citizen population will result in lower consumption and production in domestic markets, raising the welfare payment burden in the public sector, and causing difficulties in maintaining communities.

Japanese public administration system has three levels: national, prefectural, and municipal. Prefectural and municipal governments are responsible for policies in the sphere of education, welfare, safety and security, fire and disaster prevention, area planning and zoning, development and maintenance of local-level infrastructure, and industrial development. The governments use their own budget funds and/or subsidies from the national government. It is necessary to pay attention to demographic changes on the prefectural and municipal level to understand the issues related to city shrinkage in Japan.

The relative loss of population in some prefectures will be higher than others, according to the study of the National Institute of Population and Social Security Research [6, p. 56]. Only Tokyo Metropolitan will gain population (100.7) and a small number of prefectures can maintain their current population levels: Okinawa Prefecture (99.6), Aichi Prefecture (92.2\%), and Kanaga- wa Prefecture (91.1). On the other hand, prefectures which have larger rural areas will experience further depopulation in 2045: Akita Prefecture (58.8\%), Aomori Prefecture (63.0), Yamagata Prefecture (68.4), Kochi Prefecture (68.4), and Fukushima Prefecture (68.7).

If we compare the population in 2050 with the population in 2010 per square kilometer, we will see shows that the population will increase only on $2 \%$ of the Japanese land [7]. 19\% of the land will become deserted in 2050, 44\% will lose more than $50 \%$ of the population. In smaller municipalities, the rate of population will be falling faster. On average, Japan will lose about $24 \%$ of population between 2010 and 2050. Million-plus cities will lose $15 \%$ of their population, while municipalities with less than 10 thousand inhabitants will lose as much as $48 \%$ of their population. These estimates indicate that Tokyo, Nagoya (the capital city of Aichi Prefecture), and Yokohama (the capital city of Kanagawa Prefecture) will have to attract financial and human capital from other parts of the country.

Municipalities with a small percentage of young women are likely to lose their residents in the future, and 523 municipalities in Japan $(29.1 \%$ of all the municipalities) will only have the population of less than 10 thousand in 2040, finding it hard to keep up with other, more prosperous municipalities [8]. The number of young women aged 20-39 can be used as a proxy indicator for the reproduction capacity of a municipality since it is women who bear the reproductive responsibility: from giving birth to children to raising them. Municipalities without job opportunities for women and their partners will lose this part of the population, and the reproduction capacity of the municipalities will inevitably decline.

As it was mentioned above, in the 2040s or 2050s, large cities in Japan will become more convenient for living and more prosperous, which will attract more people while smaller cities will lose their population both in absolute and relative terms.

\section{The issue of shrinking municipalities and local SMEs in Japan}

Depopulation in rural municipalities due to the exodus of young workers to urban areas is not a new phenomenon. Japan had an experience of massive internal migration of youth labor force during the high economic growth period in the 1960s. The rapid development of manufacturing 
industries led to migration of young people to big cities such as Tokyo, Yokohama, Nagoya, and Osaka after high school, or even after junior high school. Regions without a strong industrial base became suppliers of youth labor, and they started to suffer from the shortage of young people. Figure 1 illustrates the trends of internal migration since the 1950s.

Fluctuations of population in regional cities is closely linked to the economic situation and business activities of local small- and medium-sized enterprises (SMEs). Researchers point out two periods when the economic situation and activities of SMEs in regional cities drastically changed: one is the "bubble economy" period (1985-1992), and the other is the period of the economic structural reforms (2003-2006) [8]. The former period was the time when manufacturing firms left Japan due to the sudden and continuous strengthening of the Japanese yen. Regional cities started losing their manufacturing SMEs. The latter period was the time of privatization, deregulation, and business liberalization in the conditions of the long-lasting recession. Reduced public investment weakened local construction firms, which had relied on public procurement. Large national chain stores were stimulated by the deregulation to come to local markets in regional cities and, as a result, small retailers lost their customers. Regional economies started shrinking and local SMEs became less active because of these changes.

The following discussion shows that struggling SMEs in regional cities and the shrinkage of these regions are closely related. Depopulation, financial losses of local firms, the loss of local amenities, and the shrinkage of cities are interrelated phenomena.

According to the Establishment and Enterprise Census, there were considerable differences between the characteristics of manufacturing SMEs and their business environment -"as though they were in different countries" - before and after the bubble economy [9, p. 197]. Before 1985, manufacturing SMEs were dependent on export to US markets, they also had young and entrepreneurial owners. The Plaza Accord was signed in 1985, when the US dollar was depreciated in relation to the Japanese yen and German mark. Exporters to US markets suffered. The appreciation of the Japanese yen was an indirect cause of the bubble economy, which had collapsed by 1992. After 1992, business characteristics of manufacturing SMEs were different in many aspects: they were more focused on China and Asian countries as production sites and markets and had to meet public demands such as the demand to be more environmentally friendly, engage in recycling, and use new technologies (ICT). They also had to deal with challenges in business succession. The above-described factors together with the loss of jobs accelerated the economic shrinkage in regional cities.

According to the data of the National Population Census, which was conducted every five years, there were two major depopulation cycles in Japanese regional municipalities: one started around 1985, and the other, after 2000 [10, p. 147].

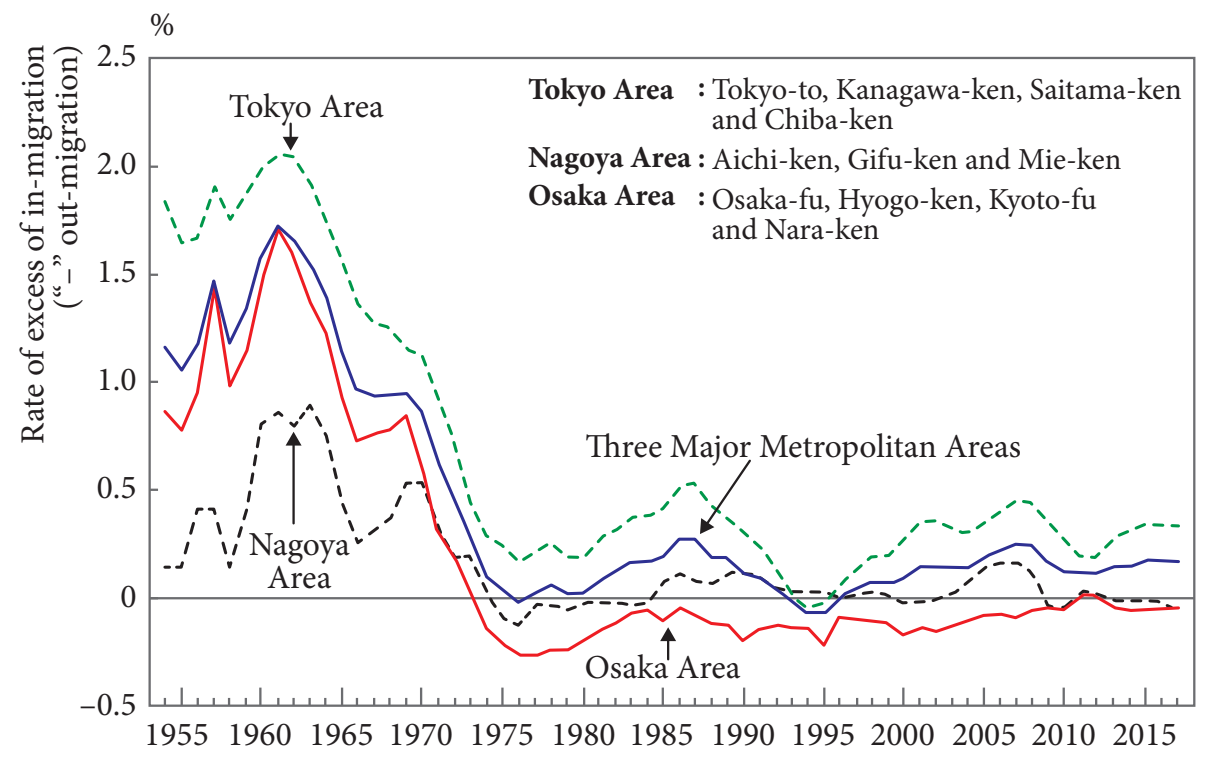

Figure 1. Historical changes in the rate of net migration for three major metropolitan areas in 1955-2017 Source: Statistical Bureau of Japan, Summary of the Results of Internal Migration in 2017. Retrieved from: https://www.stat.go.jp/english/data/idou/2017np/index.html 
Both years marked the turning points of the Japanese economy, which affected regional economies as well. The appearance of shopping malls, DIY stores, large-scale discount stores and home electric appliance stores has had a strong negative impact on regional economies since late 1990s. These large stores do not have headquarters in regional cities, which means that their profits do not stay inside the regions, at the same time local businesses lose their clients. The impact became prominent early in 2000, when local construction business started to shrink because of its diminished participation in public investment projects. Construction business at that time functioned as a quasi-system of income redistribution. Thus, the loss of jobs in construction industry negatively influenced the incomes of local residents [10, pp. 49-50].

This situation occurred during the long-lasting recession and deflation, creating a vicious circle of lower incomes and lower consumption: as the revenues of local businesses dropped and profits flowed out of the region, local inhabitants' incomes fell, which means that they cut their expenses, which led to more losses of local business and, therefore, redundancies. After 2006, new jobs in regional cities were created mainly in nursing care and consumer services. Many jobs in these industries are non-regular and are paid less than in manufacturing industries. Thus, new jobs did not lead to a higher income level in regional economies.

Figure 2 shows the vicious circles that cities were caught in. By "products" we also mean services.

\section{Initiatives to deal with the shrinkage problems}

It will be impossible to stop the shrinkage of regional cities so long as the total population of Japan is becoming smaller. However, it is possible and in fact necessary, to reduce the rate of depopulation in regional cities so that they can "win time" to establish values, norms, and rules that will enable them to create smaller but balanced societies. For this purpose, it is important to create jobs in regional cities and enable people who live there maintain the necessary level of income. By "initiative" we mean a set of consistent ideas which result in clear and coherent policies, projects and programs to solve issues and / or to achieve goals.

\section{Goal for shrinking cities: enhancement of economic resilience}

Sustainable planning models for shrinking communities is one of the seven strategic priority areas for local socio-economic development in

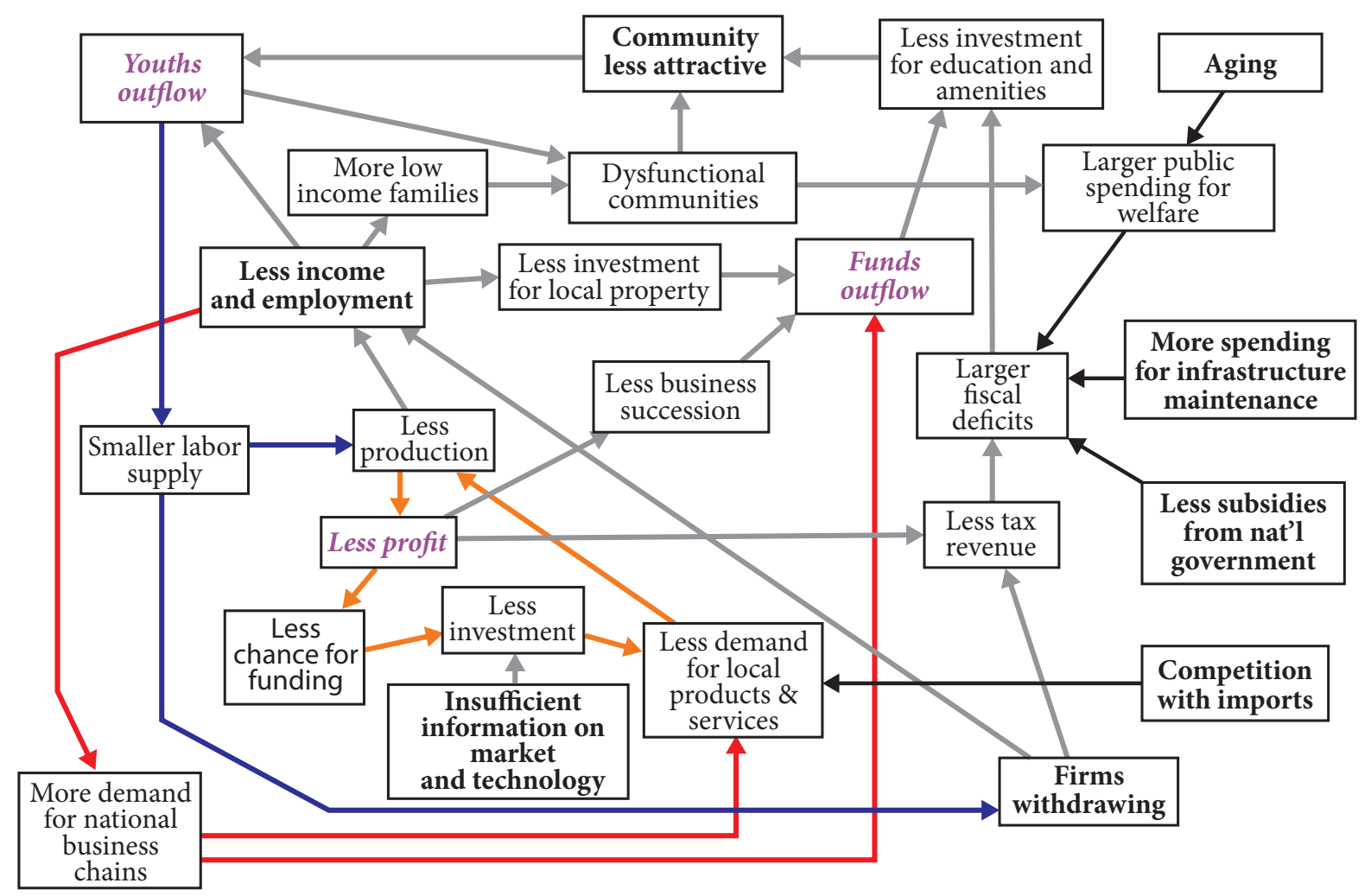

Figure 2. "Vicious circles" in shrinking cities

(The scheme was built by the author based on the discussion in Kondo (2010)) 
view of demographic change scenarios: "addressing the issue of sustainable development models that move away from the growth paradigm requires different instruments and strategies strongly anchored to the local situation and the manifestations of shrinkage" [11, p. 30].

It is necessary to stimulate local firms to create jobs, to raise the income of local residents, and to promote circulation of funds at the local level to mitigate the impact of the shrinkage and enhance economic resilience. Without attractive jobs and career prospects, young people will migrate to other regions and towns. Local economy cannot be sustained if residents' income is low or funds continue to leak out of the area.

It is usually effective to support basic industries, that is, the industries with output larger than local demand so that the surplus could be exported and bring more funds in return. Basic industries are the key to sustaining and developing local economy. The income brought by basic industries can be used to finance imports and taxation. Basic industries can be manufacturing, agriculture, or even tourism depending on the geographical and historical background of the area. It should be noted, however, that stimulation of basic industries in a city may not directly lead to economic development, especially when their products are not competitive, which can be addressed by lowering the price but in this case residents' incomes will not rise and, therefore, the desired effect will not be achieved.

Import replacement in a city is essential for understanding the rise and decline of the city's wealth and growth. Successful cities have good pro-business "eco-systems": "Economies producing diversely and amply for their own people and producers, as well as for others, are better off than specialized economics like those of supply, clearance, and transplant regions. In a natural ecology, the more diversity there is, the more flexibility, too, because of what ecologists call its greater numbers of "homeostatic feedback loops", meaning that it includes greater numbers of feedback controls for automatic self-correction. It is the same with our economies" [12, p. 224].

It is important that unique strategies should be designed and introduced to ensure economic development in shrinking cities: "Designing skills and employment strategies for these cities requires different approaches from cities that are growing and where skills shortages relate to strong industrial demand. Declining cities need to work much harder at offering lifestyle choices together with a dynamic business environment that can attract and keep knowledge workers and their families." $[13 ; 221]$

\section{Governmental initiatives in Japan: long-term vision and comprehensive strategy for regional revitalization}

The Japanese government acknowledged that the country would face a structural crisis of nation-wide depopulation and aging and established the Headquarters for Regional Revitalization under the Cabinet in September 2014 to deal with the issue. Mr. Shigeru Ishiba, one of the leaders of the government party at the time, was appointed as the first Minister of State for Regional Revitalization. In December 2014, the Headquarters issued the Long-term Vision for Regional Revitalization (hereinafter referred to as "Vision"), and the Five-Year Comprehensive Strategy for Regional Revitalization (hereinafter "Comprehensive Strategy").

The Comprehensive Strategy described goals, fundamental approaches, and projects of regional revitalization for the period 2015-2019. The Strategy set four main goals: (1) creating jobs in regional cities; (2) attracting investment to regional cities; (3) implementing family policies targeting the young generation; and (4) disaster prevention. The national government passed a new law, the Law for Regional Revitalization, in 2014, which demanded that all the prefectural and municipal governments should do their best to prepare their own population visions and comprehensive strategies for revitalization, so that local governments could start implementing their own projects. The national government provided local governments with information support, human resources and funds ${ }^{2}$.

Currently, all the prefectural and municipal governments, except for one municipality, have their own prefectural/municipal revitalization strategies. Almost all of the local governments (100\% of prefectural governments and $91.8 \%$ of municipal governments) evaluated the effectiveness of their strategies. Their evaluation showed that more than $90 \%$ of the local governments prepared their strategies with the assistance of advisors in their regions, while some municipalities

2 The information in this paragraph is taken from "Machi, Hito, Shigoto Sosei Kihon Hoshin (Basic Approach for Regional Revitalization) 2019”. Retrieved from: https://www. kantei.go.jp/jp/singi/sousei/info/pdf/r01-06-21-kihonhousin2019hontai.pdf 
preferred to employ consulting firms to draw their comprehensive strategies due to time constraints ${ }^{3}$.

\section{Alternative initiative - empowerment of local SMEs}

The governmental initiative is not the only available approach to solving the problem of shrinking cities. An alternative initiative focusing on the empowerment of SMEs in cities, will complement the government's initiative in terms of job creation and income generation.

It makes sense to support local SMEs in order to revitalize local economies. Three roles of SMEs in regional cities are important for their sustainability: (1) generating income by selling local products to customers living outside the area; (2) creating job opportunities for local residents; and (3) supporting local residents. Seki also claims that these roles are particularly significant if we want to deal with the problems of depopulation and aging [9, p. iv]. SMEs in regional cities should enhance their capacity for product development and proactive marketing. Business development in shrinking cities should focus on creating, expanding, and renewing networks of entrepreneurial business owners, providing them with access to new information and new business connections. Arrangements to make business owners more entrepreneurial will also produce positive results. All of the above-described measures can contribute to business growth and innovation.

Business incentive policies, such as offering tax breaks and/or subsidies to local firms, have been recommended to promote regional economic development. Such policies encourage local firms to increase investment, employ competent workers, and to implement innovation. However, they are not always effective in shrinking cities. Policy-makers assume that local business owners are entrepreneurial and they are in competitive markets but markets in shrinking cities, on the contrary, are often not competitive and business owners tend to have oligopolistic rents. Business incentive policies will not always encourage innovation, but will rather increase the rents of current business owners.

\footnotetext{
${ }^{3}$ The information in this paragraph is taken from "Dai 1-ki 'Machi, Hito, Shigoto Sosei Sogo Senryaku' ni Kansuru Kenshokai Chukan Seiri (Interim Report from the Review Council on Comprehensive Strategy for Regional Revitalization)". Retrieved from: https://www.kantei.go.jp/jp/singi/sousei/meeting/senryaku kensyou/r01-05-31 chuukan.pdf
}

\section{Economic gardening}

This paper claims that "economic gardening" can improve the economic resilience of small cities. Economic gardening is an entrepreneurial alternative to traditional economic development strategies. This new approach, created in the City of Littleton, Colorado, US by Christian Gibbons and his supporters in response to massive corporate layoffs, uses high end corporate-level tools and cutting-edge scientific concepts to help entrepreneurial growth companies identify markets, monitor competitors, track industry trends, locate customer clusters on maps, and use search engine optimization (SEO) / Google Adwords / social media for marketing and various customized research.

Economic Gardening was created in 1987 and implemented starting from 1989. Some of the best practices had emerged by the late 1990s. In terms of job creation, Littleton even outperformed when economic gardening was in operation: "Since the introduction of economic gardening principles in 1989, the number of new jobs in Littleton has grown from 14,907 to 35,163 , or 136 percent. These numbers include wage-and-salary jobs plus self-employment. This growth is approximately twice the rate of Denver region, three times that of Colorado, and six times that of the United States" [14, pp. 173].

Employment rates continued to be high even during the recession just after the turn of the century in the US: "Littleton's 35 percent job growth between 2000 and 2005 well exceeds that of comparable inner suburban Denver communities of similar size: Englewood (7.3 percent), Northglenn (6.2 percent), and Thornton (21.4 percent)" [14; 174].

Economic gardening model was adopted by a number of communities and states including Wyoming, Oregon, and Florida. There was an urgent need to maintain the authenticity of the model because some economic development consultants might have been tempted to imitate economic gardening and damage its brand image. Gibbons and his team in Littleton had official duties to serve their clients and could not travel much across the country despite the growing interest in economic gardening. The Edward Lowe Foundation established the National Center of Economic Gardening in 2009. The Center now provides training programs for certified economic gardening managers and offers professional services to state centers or regional centers. 
Economic gardening is not an application of specific economic theories. Instead, its creators cooperated with David Birch (jobs and SMEs), Paul Romer (endogenous growth), and researchers at the Santa Fe Institute (complexity science).

Economic gardening is different from traditional economic development strategies in many aspects. First, it is based on an idea that economies are driven by entrepreneurial growth and by innovation rather than the cheapest place to do business. Second, the public has three major roles: information, infrastructure, and connections. Third, the model focuses on companies' growth companies, especially at Stage II (10-99 employees). Fourth, it uses sophisticated corporate tools, such as database searching, geographic information systems, search engine optimization, web marketing, social media research tools, and network mapping. Moreover, it focuses on front-end and strategic issues of business, such as core strategy, market dynamics, marketing, teams, and finance. It depends on a highly skilled economic gardening staff working in an iterative manner with business owners. Finally, the economic gardening organization should be as entrepreneurial as the companies with which it works [15, pp. 6-7].

Economic gardening in Littleton was realized in accordance with the following principles as described by C.Gibbons:

- "Power laws (80/20 rule) that revealed a few companies made a whole lot of difference and a lot of companies made a little bit of difference;

- Network theory that described a critical factor in business success;

- Commodity traps which explained why standards of living weren't rising in agricultural areas and 'business friendly' manufacturing areas;

- Temperament which turned out to be a big factor in company growth; and

- Complexity science which said that economies were not in equilibrium and in fact were far from equilibrium - which in turn nicely explained the turbulent 'gales of creative destruction' identified by Schumpeter a half century before" $[15$, p. 6].

The primary beneficiary of economic gardening is certainly the entrepreneurs and firms in the community that implements the program. In addition, economic gardening serves the interests of the community making it more economically resilient through diversification of businesses, development of connection among businesses, universities, and other supportive organizations, and through making the businesses more informed and intelligent.

Economic development through business recruitment was popular in the US and Japan, but it did not make the region more resilient because recruited firms or production plants usually moved to other regions in search of better business opportunities. Economic gardening is an effective approach to building regions with economic resilience, and it brought good results in many American municipalities.

Economic gardening was also tested in cities outside the US. The City of Shellharbour in New South Wales, Australia, started their economic gardening project in 2006. Cities of Wollongong and Kiama joined later, and currently the beneficiaries of economic gardening are open to local businesses of the three cities [16]. Local governments in Japan have started their own economic gardening projects in the last decade: Fujieda City in 2011, Naruto City in 2012, Osaka Prefecture in 2014, and Sammu City in 2016.

\section{Case Study}

\section{Proposed framework for comparative case study analysis}

This paper proposes a framework for comparative case study analysis of shrinking cities in Russia and Japan. The framework comprises the following components:

(1) Profile of the city with the history of city shrinkage;

(2) Characteristics of local SMEs;

(3) Institutional aspect of the programs;

(4) Business support activities;

(5) Evaluation and future development

\section{The case of Sammu City}

Sammu City, with the population of about 51,600 , has been trying to support local SMEs. Anticipating that they are going to lose more population in the future, the government officially started an economic gardening project in 2016 after two years' preparation. The city's business support program is unique in that the city government and the local economic organization formed an equal partnership. Practical business support measures are provided through working groups involving business owners. They have not implemented post-program surveys yet to identify and confirm the effectiveness of the initiative. However, it is necessary to pay attention to networks 
of businesses and to the rules for planning SME support programs.

(1) City profile: Sammu City is located in the northwestern part of Chiba Prefecture, approximately $70 \mathrm{~km}$ away from central Tokyo. The population of the city is about 51,600 as of April in 2019 , but it has been losing about $2 \%$ of its population every year since 1990s (see Figure 3). Their major industries are manufacturing, services, and construction (see Figure 4). Agriculture is not prominent in terms of output and employment, but people in the city are very proud of their agriculture-based culture and their superior agricultural products such as rice and strawberry. Sammu City is one of the municipalities in Japan where economic gardening principles have been implemented.

(2) Characteristics of local SMEs: Following the recommendation by the Sammu Economic
Gardening Preparatory Committee, Sammu City Government conducted a comprehensive survey on SMEs in the city to understand its business environment that affected local businesses. The information for Tables 1-9 was taken from the internal survey report published by Sammu City Government in March 2016: Shinai Chushokigyo Shokibojigyosha Jittaichosa Hokokusho (Survey Report on Small- and Medium-Sized Enterprises and Sole Proprietors in the City). Survey questionnaires were sent to 1,758 businesses (firms and sole proprietors). 841 of them (47.8\%) responded.

Table 1

Number of employees

\begin{tabular}{|l|c|c|c|c|}
\hline Nr of employees & $\mathbf{0 - 5}$ & $\mathbf{6 - 1 0}$ & $\mathbf{1 1 - 5 0}$ & $\mathbf{5 1}$ or above \\
\hline Percentage & $55.2 \%$ & $11.9 \%$ & $14.9 \%$ & $4 \%$ \\
\hline
\end{tabular}

Comments: $82.0 \%$ of the respondents work in businesses with 50 employees or less.

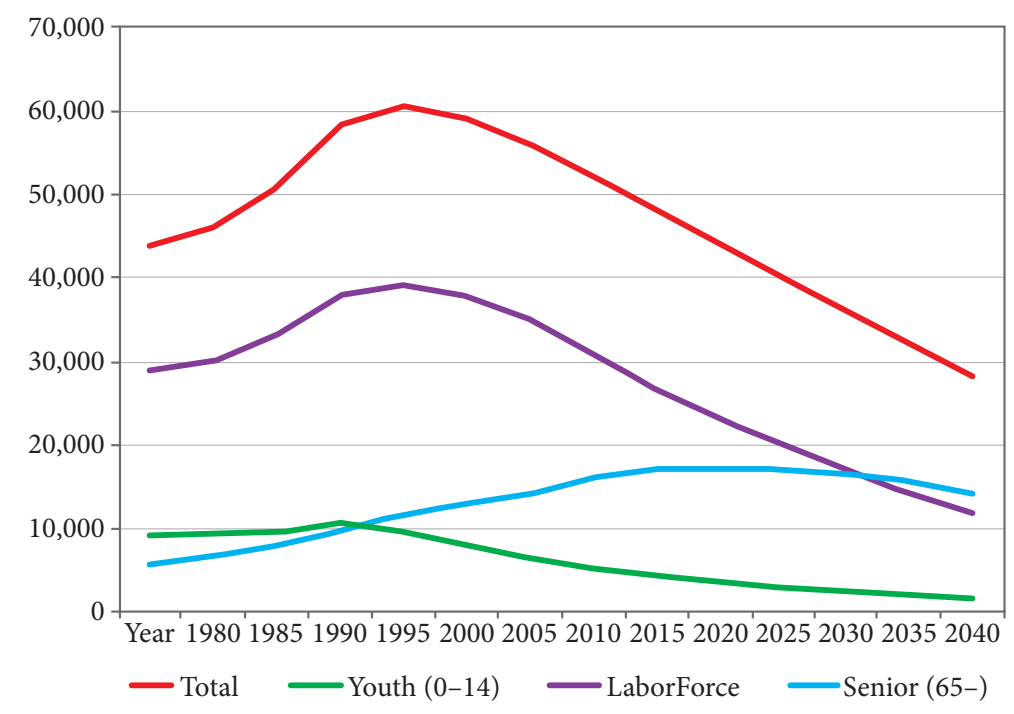

Figure 3. Population change in Sammu City

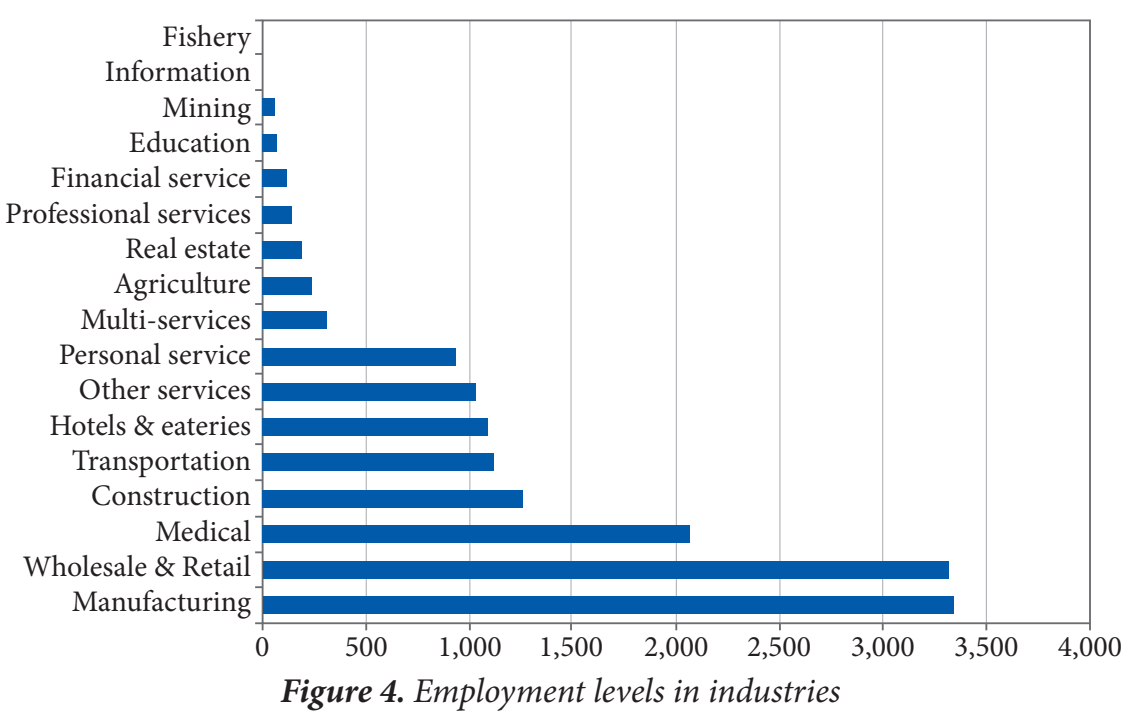


Table 2

Type of organization

\begin{tabular}{|c|c|c|}
\hline Type & Firms & Sole Proprietors \\
\hline Percentage & $54.4 \%$ & $42.3 \&$ \\
\hline \multicolumn{2}{|c|}{ Comments: We can safely assume that most small business- } \\
es with employees of 5 or less are owned by sole proprietors.
\end{tabular}

Table 3

Age of business owners

\begin{tabular}{|c|c|c|c|c|c|}
\hline Age & $\begin{array}{c}\mathbf{4 0} \text { or } \\
\text { under }\end{array}$ & $\mathbf{4 1 - 5 0}$ & $\mathbf{5 1 - 6 0}$ & $\mathbf{6 1 - 7 0}$ & $\begin{array}{c}\mathbf{7 1} \text { or } \\
\text { above }\end{array}$ \\
\hline Percentage & $5.2 \%$ & $14.3 \%$ & $20.6 \%$ & $35.2 \%$ & $22.1 \%$ \\
\hline
\end{tabular}

Comments: More than a half (57.3\%) of business owners are 61 or older. The majority of the respondents are seniors and pre-seniors.

Table 4

Top five industries

\begin{tabular}{|l|c|c|c|c|c|}
\hline Industries & $\begin{array}{c}\text { Con- } \\
\text { struc- } \\
\text { tion }\end{array}$ & $\begin{array}{c}\text { Per- } \\
\text { sonal } \\
\text { service }\end{array}$ & $\begin{array}{c}\text { Gro- } \\
\text { cery }\end{array}$ & $\begin{array}{c}\text { Com- } \\
\text { merce }\end{array}$ & $\begin{array}{c}\text { Medical } \\
\text { or nursing } \\
\text { care }\end{array}$ \\
\hline Percentage & $14.1 \%$ & $11.2 \%$ & $9.9 \%$ & $7.8 \%$ & $7.0 \%$ \\
\hline
\end{tabular}

Comments: Industrial composition in Sammu is diverse, while these top 5 industries account for about a half of their industries.

Location of current clients

Table 5

\begin{tabular}{|c|c|c|c|c|c|c|}
\hline $\begin{array}{c}\text { Location } \\
\text { of current } \\
\text { clients }\end{array}$ & $\begin{array}{c}\text { Same } \\
\text { city } \\
\text { (Sam- } \\
\text { mu) }\end{array}$ & $\begin{array}{c}\text { Neigh- } \\
\text { bor } \\
\text { cities }\end{array}$ & $\begin{array}{c}\text { Same } \\
\text { prefec- } \\
\text { ture } \\
\text { (Chi- } \\
\text { ba) }\end{array}$ & $\begin{array}{c}\text { Neigh- } \\
\text { bor } \\
\text { prefec- } \\
\text { tures }\end{array}$ & $\begin{array}{c}\text { Other } \\
\text { areas } \\
\text { in } \\
\text { Japan }\end{array}$ & $\begin{array}{c}\text { Over- } \\
\text { seas }\end{array}$ \\
\hline
\end{tabular}

\begin{tabular}{|l|l|l|l|l|l|l|} 
Percentage & $25.7 \%$ & $12.7 \%$ & $24.5 \%$ & $6.9 \%$ & $14.7 \%$ & $0.1 \%$ \\
\hline
\end{tabular}

Comments: A quarter of the respondents have clients in Sammu City; more than a half of the respondents have clients outside the city.

\section{Desired location of clients in the future}

\begin{tabular}{|c|c|c|c|c|c|c|}
\hline $\begin{array}{c}\text { Desired } \\
\text { location } \\
\text { of clients }\end{array}$ & $\begin{array}{c}\text { Same } \\
\text { city } \\
\text { (Sam- } \\
\text { mu) }\end{array}$ & $\begin{array}{c}\text { Neigh- } \\
\text { boring } \\
\text { cities }\end{array}$ & $\begin{array}{c}\text { Same } \\
\text { prefec- } \\
\text { ture } \\
\text { (Chiba) }\end{array}$ & $\begin{array}{c}\text { Neigh- } \\
\text { boring } \\
\text { prefec- } \\
\text { tures }\end{array}$ & $\begin{array}{c}\text { Other } \\
\text { areas } \\
\text { in } \\
\text { Japan }\end{array}$ & $\begin{array}{c}\text { Over- } \\
\text { seas }\end{array}$ \\
\hline Percentage & $328 \%$ & 25 & $23.4 \%$ & $10.3 \%$ & $13 \%$ \\
\hline
\end{tabular}

\begin{tabular}{|l|l|l|l|l|l|l|}
\hline Percentage & $32.8 \%$ & $25.1 \%$ & $23.4 \%$ & $10.3 \%$ & $13.3 \%$ & $3.0 \%$ \\
\hline
\end{tabular}

Comments: More than a half of the respondents want to have clients in the same city or in neighboring cities, which means that they are interested in having clients within their arm's length. A small number of firms seek clients abroad. These firms can lead local economy.

\section{Changes in sales revenues compared} with 3 years ago

\begin{tabular}{|c|c|c|c|c|c|}
\hline Change & $\begin{array}{c}\text { In- } \\
\text { creased } \\
(<\mathbf{9 \%})\end{array}$ & $\begin{array}{c}\text { In- } \\
\text { creased } \\
(\mathbf{2 - 9 \% )}\end{array}$ & $\begin{array}{c}\text { No } \\
\text { change }\end{array}$ & $\begin{array}{c}\text { De- } \\
\text { creased } \\
\mathbf{( - 2} \text { to } \\
\mathbf{- 9 \% )}\end{array}$ & $\begin{array}{c}\text { De- } \\
\text { creased } \\
\text { (less than } \\
\mathbf{- 9 \% )}\end{array}$ \\
\hline Percentage & $3.3 \%$ & $13.3 \%$ & $28.3 \%$ & $24.9 \%$ & $24.0 \%$ \\
\hline
\end{tabular}

Comments: Almost a half (48.9\%) of the respondents said that their sales revenues decreased in the last 3 years, while a small number of firms increased their sales revenue significantly.
Table 8

Current business issues (it was possible to choose several answers)

\begin{tabular}{|l|c|}
\hline \multicolumn{1}{|c|}{ Current business issues } & Percentage \\
\hline No new clients & $29.8 \%$ \\
\hline No new employees & $29.1 \%$ \\
\hline Declining sales & $26.6 \%$ \\
\hline High material costs & $17.6 \%$ \\
\hline Obsolete machinery / facilities & $17.4 \%$ \\
\hline Weak financial base & $12.8 \%$ \\
\hline
\end{tabular}

Comments: Six major concerns for respondents are the lack of new clients and new employees, declining sales, high material costs, the need to upgrade machinery facilities, and the weak financial base.

Table 9

\section{Need for information support from the government}

\begin{tabular}{|l|c|c|c|}
\hline $\begin{array}{l}\text { Do you need more information } \\
\text { support from the government? }\end{array}$ & Yes & No & No reply \\
\hline Percentage & $34.7 \%$ & $47.3 \%$ & $18.0 \%$ \\
\hline
\end{tabular}

Comments: Only a third of the respondents say that they want to receive business development information from the city government. Their replies do not necessary mean that most businesses in the city do not need information services. The respondents may have doubted that the city government would be able to provide useful information.

(3) Institutional aspect: Sammu City Government and the Youth League of the Sammu City Society of Commerce and Industry jointly organized the Sammu Economic Gardening Preparatory Committee in April 2014 so that both organizations could cooperate in providing more effective support for SMEs in the city. The Committee had 23 corporate members. Members of the Committee shared information on demographic changes in the past and in the future, industrial structure, and best practices in other municipalities. They also discussed how public support for local SMEs should be improved.

The Preparatory Committee launched four working groups as an experimental activity in 2015. Operation costs of the working groups were covered by the city budget. The working groups had the right to engage external experts if necessary.

By 2016, Members of the Committee had shared a view that their economy had been shrinking and would shrink further with a smaller and aging population. They also had a common recognition that the services for business development of local firms and solo proprietors needed improvement. In April 2016, the Preparatory Committee was transformed into the Sammu Economic Gardening Promotion Committee, 
which coordinates business development support projects for local businesses.

The Small- and Medium-Sized Enterprise Promotion Basic Ordinance was enacted in April 2018. The Ordinance provides an institutional justification to adopt economic gardening as an official policy.

The purpose of economic gardening in Sammu is to establish a business environment in which local firms and entrepreneurs will live long and prosper". The purpose of the Sammu Economic Gardening Promotion Committee is to enhance the effective partnership of the business, academic, public, civ$\mathrm{il}$, and financial sectors to deal with the challenges and needs of local SMEs and businesses ${ }^{5}$.

Economic Gardening Sammu ("EG Sammu") is member-based. As of December 2018, there were 73 members of Sammu Economic Gardening Promotion Committee: 36 in commerce, 15 in manufacturing, 13 in finance and public services, and 9 farmers 6 . What is special about Sammu Economic Gardening Promotion Committee is that a private sector organization (Society of Commerce and Industry) has taken the leadership. One of the Society's senior directors serves as the Chairman of the Committee, and the deputy mayor of the city serves as the Vice Chairman. The Committee delegates its decision-making powers to the standing council, which meets twice a month, so that they can flexibly respond to requests from members and beneficiaries of the business support services.

The annual budget for the programs in fiscal year 2019 is approximately US\$ 55,800 , including subsidies from the city government. Increasing financial independence from the city government is one of the points in the agenda of the Committee. The government budget may vary largely due to the political and administrative situation on the national level. It is important to gain a more stable financial base for the sustainability of the program.

(4) Business support activities: As mentioned above, practical business support measures are provided through working groups, involving business owners. Seven working groups are currently active:

\footnotetext{
${ }^{4}$ Stated in http://eg-sammu.jp/faq

${ }^{5}$ Stated in http://eg-sammu.jp/council

${ }^{6}$ Response to Mr. Kazunobu Namiki, a City Councilor, by the Director-General of the Department of Economic and Environmental Affairs, Sammu City Government, at the regular session of Sammu City Council, December 2018. Published in Sammu Shigikai Dayori (Sammu City Council Bulletin) No. 51, 1 February 2019, p. 10. Retrieved from: https://www. city.sammu.lg.jp/uploaded/attachment/21914.pdf
}

1. Local resource utilization. Members of this working group engage in research and development activities to create new commercial products made of Sammu cedar, which was a local specialty for long time.

2. "Chat Biz". In this working group, business owners develop new ideas for marketing and product design through brainstorming sessions held in the local library, which provides them with access to books and on-line databases.

3. Job fair. Every year, they organize a "job fair" for business owners who intend to hire new employees in the city and for job-seekers who look for local employers. Members of this working group are now creating short videos that capture characteristics of local firms.

4. Local tourism. Members of this working group develop new sightseeing routes for visitors and for those who are interested in moving into the city. They organize an annual tour to examine the effectiveness of their ideas.

5. Local food promotion. This working group intends to link local farmers, food manufactures, and restaurants so that they can develop new menus that use local food materials.

6. Tourism content development. Members of this working group identify local "valuables," unique and commercially viable, for tourism.

7. Businesses and banks. In sessions organized by this working group, local businessowners and those who intend to start a new business can meet representatives of bank and receive suggestions so that they can develop a better business relationship.

(5) Evaluation and future development: Sammu City has not conducted post-program surveys on the current situation of SMEs to confirm the effectiveness of the initiative, and the official statistics are not available yet. Members of the Economic Gardening Committee said, however, that sales and employment in their companies have improved or at least remained at the same level. They also said that this result was achieved because (1) they got new clients through discussion for management improvement among SME presidents; (2) their management skills became more up-to-date; and (3) they jointly developed new products and services.

Business support programs in Sammu City are different in many aspects from those in Littleton although they both use the term "economic gardening" to denote their activities. Both cities have almost the same size of population, but different cultural and institutional backgrounds for 
their economies. In Littleton, the city government provided business intelligence information to the second stage growth firms so that they could successfully make good strategic decisions. The team members for the programs in Littleton were public officials, and they were highly skilled and specialized in specific services, such as geographic information systems (GIS) and database analysis.

On the other hand, SMEs support programs in Sammu City are open to all the firms and sole proprietors in the city. This is partly because businesspersons in Sammu are not as entrepreneurial as those in Littleton and that small firms do not grow rapidly. As mentioned above, the role of city officials in working group activities was minimal. SME presidents use working groups to expand their business networks and to improve their performance. It is customary in Japanese regional cities that local firms have a stable business relationship. SMEs support policy can contribute to many firms, if they are successful, through such business networks.

Thus, it is necessary to pay attention to networks of businesses and to rules, whether written or customary, of planning SMEs support programs. This is especially important when a new approach is introduced in the economy, because something new tends to create some resistance and reluctance.

\section{Conclusion}

This paper examined the problem of Japanese shrinking cities and evaluated the policies that intend to mitigate the impact of shrinkage. The paper consists of three sections. The first section discussed analytical issues, including the definition of a shrinking city, which can be used for international comparative research. Based on the definition, this paper examined Japan's depopulation in the coming decades at the national and municipal level. Then, this paper illustrated that the population loss in regional cities and their change of economic structure have been closely related as parts of a vicious circle. This paper claimed that restoring and improving business activities by local SMEs is a necessary, if not a sufficient condition for revitalization of shrinking cities in Japan.

The second section of the paper examined the desired policy goals for shrinking cities, along with strategies and approaches to achieve such goals. This paper stressed that impacts of the shrinkage should be mitigated and economic resilience should be enhanced. The strategies that Japan's national government has employed since 2014 were inadequate to these goals. An alternative initiative - economic gardening - to complement the government initiative in terms of job creation and income generation was proposed in this paper. Economic gardening, implemented in the US, Australia, and Japan, can be a good strategy for further economic development in shrinking cities in Russia.

The third section of the paper is a case study of a Japanese shrinking city, which has been implementing the economic gardening model. This case study is based on the proposed framework for comparative case study analysis of Russian and Japanese shrinking cities. Sammu City, with the population of about 51,600 , officially started the economic gardening project in 2016 after two years' preparation. The City's business support program was unique in that the city government and a local economic organization formed an equal partnership. There has been no such partnership for local economic cooperation in Japan. Sammu City has not conducted any post-program surveys on the current situation of SMEs to confirm the effectiveness of the initiative, and the official statistics are not available yet. However, sales and employment of the local firms that participated in the program have improved or at least remained at the same level.

Future research might examine the effectiveness of programs for revitalizing shrinking cities in resource-dependent regions in different countries such as Russia and Australia, to make insightful suggestions and provide recommendation for adequate policy formulation and implementation.

\section{References}

1. Hollander, J. B., Pallagst, K., Schwarz, T., \& Popper, F. J. (2009). Planning Shrinking Cities. Progress in Planning, 72(4), 223-232.

2. Richardson, H. W., \& Nam, C. W. (2014). Shrinking Cities - A Global Perspectives. London: Routledge.

3. Kühn, M., \& Fischer, S. (2011). Strategic Planning - Approaches to Coping with the Crisis of Shrinking Cities. In: B. Müller (Ed.) German Annual of Spatial Research and Policy 2010 (pp. 143-146). Heidelberg: Springer-Verlag. 
4. Wu, C. T., Zhang, X. L., Cui, G. H., \& Cui, S. P. (2014). Shrinkage and Expansion of Peri-Urban China. In: K. Pallagst, T. Wiechmann, C. Martinez-Fernandez (Eds.), Shrinking Cities - International Perspectives and Policy Implications (pp. 164-185). London: Routledge.

5. Yang, Z., \& Dunford, M. (2018). City Shrinkage in China: scalar process of urban and hukou population losses. Regional Studies, 52(8), 1111-1121. DOI: 10.1080/00343404.2017.1335865

6. National Institute of Population and Social Security Research (2018). Regional Population Projections for Japan: 2015-2045. Population Research Series No. 340. Retrieved from: http://www. ipss.go.jp/pp-shicyoson/j/shicyoson18/6houkoku/houkoku.pdf (In Japan.)

7. Spatial Policy Research Group, under the Ministry of Land, Infrastructure, Transportation, and Tourism (2014). "Kokudo no Gurando Dezain" ga Egaku Kono Kuni no Mirai (The Future of the Nation, which "the Grand Design of National Spatial Development towards 2050" Illustrates). Tokyo: Taisei Shuppansha. (In Japan.)

8. Masuda, H. (2013). 2040 nen Chiho Shometsu Kyokuten Shakai ga Torai suru (Local Cities Disappear in 2040 - Coming of Polar Society). Chuo Koron, December 2013, 26-27. (In Japanese)

9. Seki, M. (2017). Nihon no Chusho Kigyo (Japanese Small- and Medium Enterprises). Tokyo: Chuko Shinsho. (In Japan.)

10. Kondo, S. (2011). Jungen Dantai (Municipalities with Net Depopulation). Tokyo: Shin-hyoron. (In Japan.)

11. Martinez-Fernandez, C., \& Weyman, T. (2012). The Crossroads of Demographic Change and Local Development. In: C. Martinez-Fernandez, N. Kubo, A. Noya, T. Weyman (Eds.) Demographic Change and Local Development: Shrinkage, Regeneration and Social Dynamics (pp. 15-35). Paris: OECD Publishing. House.

12. Jacobs, J. (1985). Cities and the Wealth of Nations, Vintage Book Edition. New York: Random

13. Martinez-Fernandez, C., Audirac, I., Fol, S., \& Cunningham-Sabot, E. (2012). Shrinking Cities: Urban Challenges of Globalization. International Journal of Urban and Regional Research, 36(2), 213-225.

14. The US Small Business Administration (2006). Economic Gardening: Next Generation Applications for a Balanced Portfolio Approach to Economic Growth. In: The Small Business Economy for Data Year 2005: A Report to the President (pp. 157-193). Washington, D.C.: United States Government Printing Office.

15. Gibbons, C. (2010). Economic Gardening - An Entrepreneurial Alternative to Traditional Economic Development Strategies. The IEDC Economic Development Journal, 9(3), 5-11.

16. Grace, J. (2013). Building Entrepreneurial Culture in a "Company Town": Innovative Initiatives in the Illawarra. In: S. Kinnear, K. Charters, P. Vitartas, (Eds.), Regional Advantage and Innovation (pp. 319-337). Heidelberg: Springer-Verlag.

\section{Information about the author}

Takashi Yamamoto - PhD in Economics, Professor, Department of Economics, Takushoku University (Kohinata 3-4-14, Bunkyo, Tokyo, 112-8585, Japan); e-mail: ytakashi@ner.takushoku-u.ac.jp

ARTICLE INFO: received June 5, 2019; accepted August 26, 2019

\section{Информация об авторе}

Ямамото Такаши - $\mathrm{PhD}$ по экономике, профессор, департамент экономики, Университет Такусёку (Кохината 3-4-14, Бункё, Токио, 112-8585, Япония); e-mail: ytakashi@ ner.takushoku-u.ac.jp

ИНФОРМАЦИЯ О СТАТЬЕ: дата поступления 5 июня 2019 г.; дата принятия к печати 26 августа 2019 г.

This work is licensed under a Creative Commons Attribution 4.0 International License

Эта работа лицензируется в соответствии с Creative Commons Attribution

4.0 International License 